\title{
The role of social protection structures in the economic integration of refugees: analysis of Syrian refugees in the city of São Paulo
}

\author{
${ }^{1}$ Fundação Getulio Vargas (FGV EAESP) / Escola de Administração de EMPreSAS de SÃo Paulo, SÃo PaUlo - SP, BrazIL
}

\begin{abstract}
This paper aims to analyze the role of social protection structures in the economic integration of refugees. While most of the literature on economic integration focuses on refugee access to formal workforce, this paper explores the importance of social protection in the integration process and how it paves the way for greater economic integration. This paper investigates both formal social protection structures and informal ties within immigrant communities that help refugees obtain a basic income while they are in the process of integration. Brazil has no national program for economic integration of refugees and, in terms of social protection structures, they are recipients of the same social assistance programs that are offered to the low-income population. By looking at a conditional cash transfer program, Bolsa Familia, and analyzing the access and outcomes of this program for Syrian refugees in the city of São Paulo, this paper shows the limitations of providing these programs to refugees without considering their specificities. In conclusion, for a stronger economic integration, formal structures of social protection need to be more efficient and better address refugees' needs. In order to conduct this work, I used academic and news articles, and interviewed members from the government and civil society organizations who work with refugee integration.
\end{abstract}

Keywords: Syrian Refugees. São Paulo. Economic Integration. Mosques. Social Protection.

\section{O papel das estruturas de proteção social para integração econômica dos refugiados: uma análise dos refugiados sírios na cidade de São Paulo}

\section{Resumo}

O objetivo deste artigo é analisar o papel das estruturas de proteção social na integração econômica dos refugiados. Embora a maior parte da literatura sobre integração econômica se concentre no acesso dos refugiados ao mercado formal, este artigo explora a importância da proteção social no processo de integração, bem como sua importância para abrir caminho para uma maior integração econômica. Este artigo analisa estruturas formais de proteção social e estruturas informais de solidariedade e vínculos entre as comunidades de imigrantes, que ajudam os refugiados a obter recursos básicos enquanto estão em processo de integração. O Brasil não possui um programa nacional de integração econômica dos refugiados e, em termos de estruturas de proteção social, eles são beneficiários dos mesmos programas de assistência social que são oferecidos à população de baixa renda. Ao examinar um programa de transferência condicional de renda, o Bolsa Família, e ao analisar o acesso e os resultados desse programa para os refugiados sírios na cidade de São Paulo, este artigo mostra as limitações de fornecer esses programas aos refugiados, sem considerar suas especificidades. Este trabalho conclui que, para uma maior integração econômica, as estruturas formais de proteção social precisam ser mais eficientes e atender melhor às necessidades dos refugiados. Para realizar este trabalho, foram usados artigos acadêmicos, notícias e realizadas entrevistas com membros do governo e organizações da sociedade civil que trabalham com integração de refugiados.

Palavras-chave: Refugiados sírios. São Paulo. Integração econômica. Mesquitas. Proteção social.

\section{El rol de las estructuras de protección social para la integración económica de los refugiados: un análisis de los refugiados sirios en la ciudad de São Paulo}

\begin{abstract}
Resumen
El propósito de este artículo es analizar el papel de las estructuras de protección social en la integración económica de los refugiados. Aunque la mayor parte de la literatura sobre integración económica se centra en el acceso de los refugiados al mercado formal, este artículo explora la importancia de la protección social en el proceso de integración, así como su relevancia para allanar el camino para una integración económica más efectiva. Este artículo analiza las estructuras formales de protección social y las informales de solidaridad y vínculos entre las comunidades de inmigrantes, que ayudan a los refugiados a obtener recursos básicos mientras están en proceso de integración. Brasil no cuenta con un programa nacional de integración económica de refugiados y, en términos de estructuras de protección social, ellos son beneficiarios de los mismos programas de asistencia social ofrecidos a la población de bajos ingresos. Al observar un programa de transferencias monetarias condicionadas, el Bolsa Família, y analizar el acceso y los resultados de este programa para los refugiados sirios en la ciudad de São Paulo, este documento muestra las limitaciones para brindar estos programas a los refugiados sin considerar sus especificidades. Por lo tanto, para una integración económica más sólida, las estructuras formales de protección social deben ser más eficientes y abordar mejor las necesidades de los refugiados. Para llevar a cabo este trabajo se utilizaron artículos académicos y noticias, y se realizaron entrevistas con miembros del gobierno y organizaciones de la sociedad civil que trabajan con la integración de refugiados.
\end{abstract}

Palabras clave: Refugiados sirios. São Paulo. Integración económica. Mezquitas. Protección social. 


\section{INTRODUCTION}

This paper aims to analyze the role of social protection structures in the economic integration of refugees. The economic integration of refugees generally refers to access to the formal workforce as well as the state policies and programs that guarantee their participation in the job market, such as training and language classes. However, the difficulties refugees have faced in accessing formal work in some host countries, both because of a lack of available work and the long process to get their work permits, have led them to rely on a combination of formal and informal structures of social protection. These structures are important mechanisms of economic integration, whereas their flaws and shortcomings can intensify the marginalization of refugees and increase their dependence on assistance provided by civil society organizations, as well as other consequences. In analyzing the social protection structures of refugees in the city of São Paulo, especially the Syrians, this article will argue that these structures, characterized by a rather complex combination of formal social protection and practices of collective solidarity, are usually insecure and precarious, even though they are fundamental to the economic integration of refugees. Therefore, to provide stronger economic integration for refugees, formal structures of social protection need to be more efficient and be better at addressing these refugees' specific needs.

Refugee integration has been the subject of many studies (Castles, Korac, Vasta \& Vertovec, 2002; Hynie, 2018; International Labour Organization [ILO], 2018; United Nations High Commissioner for Refugees [UNHCR], 2013). The initiatives and actions related to refugee integration are transversal and multidimensional, because they involve spatial, cultural, social, political, legal, psychological and economic aspects (Kuhlman, 1991). Integration is also a two-way process, since in order to be effective, it needs to involve changes and adaptations not only on the part of the refugees but also from the society that receives them (Ager \& Strang, 2010; Moreira \& Borba, 2017). The changes and adaptations on the part of the host country can occur in various ways, including daily social interactions and through the implementation of state programs and policies, which are the subject of this paper.

In relation to economic integration, this term refers to access to sufficient income to guarantee a basic standard of living for themselves and their families, who may live in the host countries with these refugees, or may receive remittances from them in their country of origin, or elsewhere. Even though, by definition, refugees are not motivated by economic reasons to leave their country of origin, economic integration is a fundamental aspect of the process of building and structuring a new life in the host country. Similar to all other dimensions of integration, economic integration has multiple layers of complexity, involving opportunities in the job market, state policies and incentives to guarantee that this integration occurs, and their formal structures of social protection.

These structures of social protection are a fundamental mechanism for economic integration, because they guarantee a source of income for refugees while they have not yet been integrated into the formal market. In addition, this is also an important mechanism to support refugees who, due of personal and/or family conditions, such as the elderly, single parents, and people with disabilities, have greater difficulties or are not able to participate in the labor market (Grace, Nawyn \& Okwako, 2017). In other words, given the adversities refugees face in integrating themselves into the formal workforce, economic integration needs to be addressed not only from a market-oriented perspective, which means their inclusion in the labor market, but also by recognizing that social protection that addresses their specific needs has to be a crucial part of it.

In order to perform this analysis, this article sheds light on the formal and informal social protection structures for Syrian refugees, the largest refugee community in Brazil from 2013 to 2018, in the city of Sao Paulo. Since Brazil has neither a national economic strategy nor a specific social protection structure for refugees, this paper analyzes the process through which refugees access the same formal social protection structures, here defined as social assistance programs, as Brazilian citizens do. One example of these social assistance programs is the Bolsa Familia Program, one of the largest conditional cash transfer programs in the world which provides cash to low and extremely low-income households. The paper's findings suggest that in the absence of a specific structure of formal social protection for refugees, they face difficulties in accessing these programs due to their lack of information about them, and the assistance provided to them is very limited in terms of addressing their needs. Refugees end up having to rely on support from civil society organizations and safety net structures within the refugee and immigrant communities, usually with the support of religious organizations, and with the increasing use of social media. 
To obtain the necessary information for this analysis, members of the Department of Human Rights and Citizenship of the city of São Paulo were interviewed as well as members of the civil society organizations Support Program for the Relocation of Refugees (Programa de Apoio para Recolocação dos Refugiados, PARR), and Peace Mission (Missão Paz). I also visited and interviewed members of Brazil Mosque (Mesquita Brazil), the oldest and one of the largest mosques in Latin America. In addition, I obtained data on refugees within the formal structure of social protection in the state of São Paulo from the Special Department of Social Development of the São Paulo state government. This study has also relied on news, research papers and reports on immigrants and refugees in Brazil.

The following section will present a literature review on the economic integration and social protection of refugees. After that, we will move on to a contextual section explaining the politics and legislation regarding refugees in Brazil and the national actors who are involved in the economic integration of refugees. Then, the theoretical framework to explain social protection for refugees will be presented. After that, in order to clarify which kind of social protection program is the subject of this paper, the Brazilian social protection structure will be examined and there will be an explanation of the advantages of cash transfer programs for refugees. After that, there will be an analysis of the limitations to refugee access to the Bolsa Familia program and explain how Syrians in São Paulo have found support through informal ties of solidarity within the already established Arab community in the city. To conclude, the paper's final considerations will be presented with directions in terms of further studies and policy recommendations.

\section{ECONOMIC INTEGRATION OF REFUGEES AND SOCIAL PROTECTION: A LITERATURE REVIEW}

Economic integration refers to the inclusion and participation of refugees in a host country's economy. While it is mostly recognized that this integration refers to access to formal work, it also refers to the access of means that can support refugees in rebuilding their lives and guaranteeing the basic needs of their families until they become integrated into the formal workforce. Therefore, formal mechanisms of social protection that deliver some kind of financial support to refugees are also one significant step towards economic integration. Kuhlman (1991), in his research on refugee integration in developing countries, defines economic integration as follows:

[A]dequate participation in the economy, an income which allows an acceptable standard of living; (2) access equal to that of the host population to those goods and services to which access is not determined solely by income levels; (3) the impact of refugees on the host society having been such that, on balance, the position of the various socio-economic categories within the indigenous population with respect to criteria (1), (2) and (3) has not deteriorated (Kuhlman, 1991, p. 19).

It is broadly recognized that while the right to access the labor market, through wage-earning employment and self-employment, is guaranteed by several international instruments on refugee protection and integration (the Refugee Convention of 1951 , its Protocol of 1967 and regional plans and strategies that deal with this issue), refugees face several difficulties in the process of integration and as of 2019, they were still not allowed to work in 50\% of asylum countries (UNHCR, 2019). The response of the host countries to the economic integration of refugees varies depending on the country's capacity and willingness to receive refugees as well as its economic strength.

The literature has identified a great number of problems related to the economic integration of refugees. Some examples of these difficulties are language and cultural differences (Castles et al., 2002), a lack of trust (Castles et al., 2002), the negative consequences of a lengthy and bureaucratic process to advance their asylum status and obtain work permits (Hainmueller, Hangartner \& Lawrence, 2016), the lack of recognition by the governments of some host states on the importance of integrating refugees into the economy, the challenges in the receiving country of accepting a great influx of refugees (Bahar, Dooely \& Huang, 2018), perceived threats that refugees are an economic burden for society (Hynie, 2018), and discrimination and xenophobia (Mayadas \& Elliott, 1992).

While most of the literature on the economic integration of refugees discusses their integration into the labor market, few works have addressed the structures of social protection which they have to rely on until their inclusion in the formal workplace occurs. According to the literature on social protection, formal social protection structures are public policies and actions that seek to directly support the population in need either due to economic vulnerabilities and life contingencies (social insurance 
programs, such as pensions and unemployment support) or to deprivation (social assistance programs, such as social services, food and school vouchers, stamps, and cash transfers) (Barrientos \& Hulme, 2008, p. 3). The dimension and scope of these structures, who is eligible to receive this assistance, how much and what is provided, and the design of these programs, are determined by each state and vary from one country to another.

As far as the inclusion of refugees in the social protection structures of host countries is concerned, something similar to what happens in the process of their inclusion in the formal market occurs. While there are international instruments that guarantee refugee access to social services in these host countries, they face several difficulties in accessing them in both developing and developed countries. These difficulties are related, first of all, to the conditions of these social protection structures in the host countries. Social protection mechanisms are not well developed in low- and extremely low-income countries and, in this sense, the access of refugees to social protection systems in developing countries is even more difficult. In addition, in some cases, these mechanisms are inexistent.

Second, this is also related to citizenship rights, meaning how states shape their systems of social protection, and who has the right to access them. In countries with a liberal approach to their welfare system, refugees are pushed to integrate into the formal market and little attention is given to social protection mechanisms (Castles et al., 2002). Some authors explore the idea of market citizenship, which means "the allocation of citizenship rights based on an individual's economic power and participation in the labor market" (Grace et al., 2017, p. 42). In the United States, for example, refugees are expected to work within the first six months that they arrive in the country while the country neglects the fact that there can be individuals who are not able to work due to their age or other constraints (Nawyn, 2011 as cited in Grace et al., 2018 , p. 43). In other words, the approaches some countries use to deal with refugees replicate the models used in their own welfare states.

The difficulties refugees face in integrating into the formal market and accessing formal social protection structures push them to rely on informal jobs and informal social protection structures. According to a study conducted by the International Labor Organization (ILO), although informality among refugees is a reality worldwide, this is mainly true of refugees who settle in urban areas of developing countries. Unlike formal structures of social protection, informal ones include a set of networks and relationships that provide them with a partial financial cushion through community savings, financial support within ethnic communities, and the sharing and exchange of information about job opportunities and social assistance programs that they may not otherwise know that they can access. In addition, immigrants in general, and refugees in particular, tend to face the precarity and informality of work in poor countries. In Latin America, for instance, $50 \%$ of the population's work is informal, and this market is also where immigrants and refugees tend to find work when they settle there (ILO, 2018, p. 16).

\section{REFUGEE INTEGRATION IN BRAZIL: LEGAL AND POLITICAL ASPECTS}

Brazil has signed the main international conventions for refugees: the 1951 Refugee Convention, the 1967 Convention Relating to the Status of Refugees, and has effectively participated in the creation of regional instruments to promote cooperation to deal with this issue in Latin America (the 1984 Cartagena Declaration on Refugees, the 1994 San Jose Declaration, the 2004 Mexico Plan of Action, and the 2014 Brazil Declaration and Plan of Action). Since the country's democratization process in the 1980s and the writing of the 1988 Constitution, Brazil has passed domestic laws and decrees on refugees (Moreira, 2010). In 1997, Brazil created the Refugee Statute, Law 9,474, which established the norms for refugees and asylum seekers. It defined a refugee as "every person who leaves his/her country of origin because of a well-founded fear of persecution for reasons of race, religion, nationality, political opinion or membership in a particular social group, or due to a situation of grave and widespread human rights violations in his/her country of origin" (LAW 9.474, 1997 in UNHCR Help Brazil, webpage).

In Law 9,474, the creation of the National Committee for Refugees (Comitê Nacional para os Refugiados, CONARE) was established, and this was responsible for analyzing asylum requests on a case-by-case basis. CONARE is administrated by the Ministry of Justice, but final decisions are made by a committee that includes representatives from several government ministries - Health, Education, International Relations, and Labor - non-state organizations, represented by the religious 
organization Caritas Arquidiocesanas, and the Brazilian office of the United Nations High Commissioner for Refugees (UNHCR). Both asylum seekers and refugees have the right to obtain Brazilian documents, including a Work Permit and a Social Security Card (Carteira de Trabalho e Previdência Social - CTPS) and a Brazilian Tax ID (Cadastro da Pessoa Física - CPF), which are necessary for them to be allowed to work and register to receive benefits from social assistance programs, as will be discussed in the following section of this paper.

In the past decade, the Brazilian government has enacted three normative directives, beyond the regular process of granting refugee status, in order to respond to three specific humanitarian crises, which have considerably changed the origin and the number of refugees in Brazil. The first directive was in response to the humanitarian crisis in Haiti in 2010, and provide permanent resident visas, also known as "humanitarian visa," which allowed them to enter and work in Brazil. In 2016, Brazil had around 80,000 Haitians with humanitarian visas or in the process of becoming permanent residents (Portal Brasil, 2016). This humanitarian visa is a complementary system to the legal and normative status of refugees and asylum seekers, as Haitians fled their country not because of a well-founded fear of persecution but because of a natural disaster (Godoy, 2011). The second directive was issued in 2013 as a response to the Syrian refugee crisis (CONARE, 2013). This directive recognized the humanitarian crisis in Syria and facilitated the process of granting refugee status to individuals from this Arab country. Syrians became the largest refugee group in Brazil, with a total of 3,326 Syrian refugees in the country between 2013 and 2018 (CONARE, 2019) The third directive was enacted in 2017 to respond to a wave of Venezuelan refugees who started to cross the borders due to this country's political crisis. In addition to this, in 2019 CONARE granted refugee status to 21,432 Venezuelans (Rodrigues, 2019).

In relation to integration, the Brazilian government also has a base from which to promote refugee integration. The 1988 Brazilian Constitution guarantees the right of non-distinction between Brazilian nationals and foreigners and the universal use of Brazilian social programs. Law 9,474 presents local integration as one of three durable solutions for refugees, in addition to voluntary repatriation and resettlement. According to the law, local integration refers to the facilitation of their enrollment at all school levels and the validation of diplomas from their homeland. In addition, the law also emphasizes the fact that their atypical situation needs to be taken into consideration whenever they need to show any documents and information to consular services.

Another important aspect of the legal apparatus for refugees in Brazil is that, since it is a federation, other levels of government state and city - also have established some rights and laws for refugees and immigrants, as long as they do not hinder the rights guaranteed by the federal government. This is the true of the city and the state of São Paulo. In 2016, São Paulo's city government enacted Municipal Law 16,478/2016, which instituted the first Municipal Policy for the Immigrant Population (PMPI), defining the immigrant population as "all people who move from their habitual place of residency to Brazil, including labor workers, students, people with refugee status, stateless people, as well their families, regardless of their immigration and document status" (Sole paragraph, Art. 1, Law 16,478/2016). This law also stated that the municipal government has the responsibility to promote immigrants' integration in a transversal and multisectoral manner (Organização Internacional para as Migrações [OIM] \& Secretaria Municipal de Direitos Humanos e Cidadania [SMDHC], 2019).

States and cities have also had a role in creating and implementing social programs for refugees. The city of São Paulo hosts the Coordinating Body of Immigrant Policies and the Promotion of Decent Work within the Department of Human Rights and Citizenship (SMDHC). According to its coordinator, Jennifer Anyuli, the Coordinating Body bases its understanding on the concept that integration is not just accepting refugees, but also supporting them in their access to services and guaranteeing they can make their own choices. In this sense, the Coordinating Body promotes several actions to assist refugees, such as supporting shelters throughout the city mainly for poor and newly-arrived immigrants. Actions related to economic integration include training, the providing of information to refugees to further entrepreneurship, the promotion of events to connect immigrants with the private sector, and actions against discrimination, abuse and xenophobia. Under the SMDHC and the Department of Social Assistance (SMAS) there is also the Reference Center and Assistance for Immigrants (CRAI). Created in 2014, CRAI is a public facility that offers immigrants and refugees assistance related to their regularization, processes, rights and access to social services. 
Despite all these initiatives and the legal apparatus developed by various levels of government, most of integration initiatives for refugees are developed and implemented by civil society and non-governmental organizations, with some incentives from the government (Haydu, 2011). Some examples of these organizations are Cáritas Arquidiocesana, the Adus Institute, I Know My Rights (IKMR), Peace Mission, and the PARR. Some of them provide several services while others are focused on one particular area. Their services include legal support, Portuguese classes, social and phycological assistance, shelters, and support for including immigrants in the labor market. PARR is one example of an organization that offers training and also connects registered companies with potential employees and provides support in terms of the documentation for their hiring process and their stay at the company.

While this is not an exhaustive presentation of these organizations and the actions they perform in São Paulo, it is possible to observe from their actions that when it comes to economic integration, civil society organizations are important interlocutors between refugees/immigrants and the private sector. They also play an important role in supporting and promoting entrepreneurship. However, when immigrants cannot be integrated into the formal economy either due to a lack of opportunities or because they are not able to work, the role of these organizations is more limited, and, depending on the services they offer, they can either provide some assistance (for example, shelters and meals) or help them access the social programs offered by the government, such as cash transfers.

\section{THE SOCIAL PROTECTION OF REFUGEES: A LOOK AT CASH TRANSFER PROGRAMS}

The premise of this paper is that effective economic integration for refugees is directly affected by the policies implemented by the government, as they help them secure the minimum conditions they need to take care of their basic needs until they have become integrated into the formal workforce. Among the social protection mechanisms, cash transfer programs (CTs) are particularly important. CTs have contributed to the well-being of the poor and vulnerable populations. They gained momentum at the turn of the century when several countries in Latin America started to include CTs within their social protection structures. The Bolsa Familia Program (BFP), created in 2004, is one kind of CT, having served more than 13.9 million families (around 52 million people) in 2019 (Ministerio da Cidadania, 2019).

Other social policies dealing with housing, education, and health also contribute to economic integration. For instance, there is strong evidence that effective housing policies help the economic integration of refugees (Netto, 2011). However, while all these programs contribute to favorable conditions for the economic integration of refugees, cash transfer programs provide economic integration. This happens because, in the absence of work, they guarantee a source of income so that the vulnerable poor population does not fall under the poverty line.

CT programs can also help further the legal and social integration of refugees. Legal integration refers to refugee rights and involves issues such as the right to obtain citizenship, political participation, and access to social services and programs. CTs advance this process of integration when refugees are eligible for the same programs as Brazilian nationals. Social integration is a very broad dimension of integration as it means all the interactions between native citizens and immigrants on a daily basis as well as the perceptions and feelings they have towards each other (Castles et al., 2002, p. 136; Hainmueller et al., 2016). CTs can contribute to social integration since they can stimulate interaction between immigrants and native citizens because the former become more economically active in society through the purchasing of goods in local markets and using local services, for example.

Despite the absence of a specific system for refugees, they and immigrants in general can access the same social assistance programs that native citizens do. As mentioned above, the Brazilian Constitution guarantees universal access to services and Brazil has ratified related international agreements. Therefore, refugees have a legal basis for supporting their access to Brazilian social assistance programs.

Brazil has a social assistance structure called the Unified National System (Sistema Único de Assistência Social, SUAS), which is operationalized through the co-participation of the three levels of government (federal, state and municipal). In order to have access to the Bolsa Familia and other social protection programs, such as a housing program called "My House, My Life" that grants loans to low-income households to purchase their houses, and "Social Rate Electricity", individuals have to register 
with the Unified Registry for Social Programs (CADÚnico). The CADÚnico, created in 2001, is an online registry system through which individuals include their income and their family's monthly income and expenses, and based on this information, the system defines the programs for which they are eligible.

The access depends on individual income, which is a per-capita figure. In 2017, the eligibility requirements for the program were: a) being a family with a total monthly income of $R \$ 85.00$ (US\$26.56, using the exchange rate from 2017 US\$1=R\$3.20) or less, and $b$ ) being families with children, between 0 and 17 years old, and a monthly per capita income between $R \$ 85.01$ and R\$170.00 (US\$53.12) (Caixa Econômica Federal, 2017). The minimum that a household could get from the BFP in 2017 was $R \$ 85.00$ and $R \$ 39.00$ could be added (US\$12.18) for each dependent, with a limit of five dependents (Caixa Econômica Federal, 2017). ${ }^{1}$ Bolsa Familia is conditional because members who access it have some obligations related to the children of their family, such as prenatal care, vaccination and nutrition of children up to 7 years old, as well as their school enrollment and minimum attendance.

The idea of these conditions is to tackle intergenerational poverty at the same time that the program eliminates extreme poverty through the providing of cash to the household. Before moving on to the analysis of the BFP for the economic integration of refugees, it is important to mention three aspects related to the program. The first is that there is a large number of studies that highlight important effects of the BFP beyond providing direct cash to the population. For instance, a study conducted by Rego and Pinzani (2014) showed how the program has helped the emancipation and autonomy of women as the program delivers cash to the women of the household.

The second aspect is related to the idea of poverty. The BFP defines poverty through household income. However, poverty is a rather complex and multifaceted phenomenon and different recipients of the program -- the urban and rural poor - have different needs. For instance, as opposed to the urban poor, those in rural areas are usually isolated geographically and, for this reason, have limited access to public services (Rego \& Pinzani, 2014, p. 26). In addition to the region, other aspects that distinguish the poor are ethnicity, skin color, gender, age, and the composition and structure of the family (Rego \& Pinzani, 2014, pp. 158-159). Therefore, even though the qualification for the program is the same for all households, based on income, there are other dimensions of poverty that are not addressed by the BFP. In this sense, even the greatest supporters of the program acknowledge that the BFP by itself is not enough to address all of the specific dimensions of poverty.

The third aspect is that the BFP was not initially developed to serve as a mechanism to integrate refugees. In fact, the number of refugees that benefit from the program is very small in comparison to the total number of recipients. In addition, refugees are affected by several other layers of disintegration and discrimination, such as cultural barriers, which make it harder for them to integrate into society. As suggested by UNHCR in a report on the integration of refugees in Europe,

Refugees [...] have specific needs due to, among other factors, their loss of the protection of their country; their experiences of persecution or armed conflict; their particular difficulties obtaining documentation; and the separation and loss of family which often follows as a consequence of flight. Measuring the impact of integration policies on refugees without an understanding of their particular needs may lead to misguided policy development and to a lack of the crucial support needed to avoid the long-term dependency, marginalization and isolation of refugees. This can in turn lead to an increase in irregular movements or challenge social cohesion in the host state (UNHCR, 2013, p. 11).

\footnotetext{
${ }^{1}$ The minimum income for eligibility, the assistance provided by the program, some rules related to the access, as well as the exchange rates have changed over time. Updated information about the program can be found at the Caixa website which is retrieved from http://www.caixa.gov.br/programas-sociais/ bolsa-familia/Paginas/default.aspx
} 


\section{ASSESSING THE SOCIAL PROTECTION STRUCTURES FOR REFUGEES AND THEIR ROLE IN ECONOMIC INTEGRATION}

In 2018, there were 3,326 Syrians refugees in Brazil, corresponding to 51\% of the refugees in the country (CONARE, 2019). This number is a result of the assistance provided by the Brazilian government in terms of accepting Syrian refugees in 2013, as explained above. There are groups of immigrants and asylum seekers from other nationalities which are much larger in number, but they have not received refugee status. For instance, in 2018 , the total number of asylum seekers registered by CONARE was 80,057, among which 61,681 were from Venezuela, 7,030 from Haiti, and 2,749 from Cuba (CONARE, 2019). Therefore, while Syrians represented the largest group of refugees in Brazil, the community was much smaller when compared to asylum seekers and immigrants of other origins.

Most of the Syrian refugees who have arrived in Brazil since 2013 reside in the city of São Paulo and in the greater São Paulo area, in cities such as Guarulhos, São Bernardo do Campo, and Campinas. Between 2013 and 2016, Syrians were the greatest refugee community in the state of São Paulo with 1,030 people with this status (followed by the Congo with 318, Colombia with 241, Mali with 91, Iraq with 90, and Angola with 88) (Observatório das Migrações webpage). The Federal Police estimates that there were 9,977 people seeking refuge in the state of São Paulo in 2018 (Mantovani, 2019).

According to data provided by the Special Department of Social Development of the São Paulo state government, presented in Table 1, the total number of immigrant families registered in CADÚnico in the state of São Paulo increased from 22,688 in 2013 to 93,479 in 2018, while the number of registered Syrian families increased from 2013 to 2015, and declined from 2015 to 2018. Table 2 shows the total of Syrians in the Bolsa Família Program in São Paulo state and São Paulo city, as well as the total of refugees and immigrants in the program in the state.

Table 1

Syrians and Other Immigrants/Refugees Registered in CADÚnico in the State of São Paulo (2013-2018)

\begin{tabular}{c|c|c|c|c|c|c|c|c|c|c|c|c}
\cline { 2 - 12 } & \multicolumn{2}{c|}{2013} & \multicolumn{2}{c|}{2014} & \multicolumn{2}{c|}{2015} & \multicolumn{2}{c|}{2016} & \multicolumn{2}{c}{2017} & 2018 \\
\cline { 2 - 14 } & Families & Individuals & Families & Individuals & Families & Individuals & Families & Individuals & Families & Individuals & Families & Individuals \\
\hline $\begin{array}{c}\text { Syrians } \\
\begin{array}{c}\text { Total } \\
\text { Immigr. } \\
\text { and } \\
\text { Refugees }\end{array}\end{array}$ & 22688 & 7 & 17 & 75 & 136 & 507 & 44 & 193 & 33 & 106 & 11 & 34 \\
\hline
\end{tabular}

Source: Data provided by the Special Department of Social Development of the São Paulo state government in July 2020.

Table 2

Syrians and Immigrants/Refugees in the Bolsa Família Program in the City and State of São Paulo (2013-2019)

\begin{tabular}{l|c|c|c|c|c|c|c}
\hline & 2013 & 2014 & 2015 & 2016 & 2017 & 2018 & 2019 \\
\hline $\begin{array}{l}\text { Syrians in the BFP in } \\
\text { Sao Paulo city }\end{array}$ & 0 & 3 & 19 & 11 & 20 & 6 & 20 \\
\hline $\begin{array}{l}\text { Syrians in the BFP in } \\
\text { São Paulo state }\end{array}$ & 1 & 5 & 25 & 16 & 31 & 8 & 30 \\
\hline $\begin{array}{l}\text { Total immigrants and } \\
\text { refugees in the BFP in } \\
\text { São Paulo state }\end{array}$ & 401 & 663 & 865 & 1,270 & 1,688 & 1,598 & 2,743 \\
\hline
\end{tabular}

Source: Data provided by the Special Department of Social Development of the São Paulo state government in July 2020 and October 2020.

In relation to these tables, four points need to be clarified. First, the registration in the CADÚnico is the basis on which the government provides several social services, including the Bolsa Familia. Therefore, all immigrants who receive the Bolsa Familia are registered with CADÚnico, but not all individuals who are registered in the CADÚnico receive the Bolsa Familia. Second, CADÚnico is a step in the process of accessing social programs. If some individuals do not have the necessary documentation, 
they may not receive the assistance they are eligible for. Third, even though immigrants and refugees have distinct realities, both of them need to meet the low-income household criteria to be eligible to receive the social program benefits. Fourth, as explained above, the CADÚnico and Bolsa Familia are elements of a formal social protection structure that was not designed to address the specific needs of refugees and immigrants and, as a consequence, there are a variety of problems in accessing these programs and their outcomes within the context of refugees and immigrants.

The first problem identified was a lack of information about the Bolsa Familia Program among refugees who as a result have not accessed it, and also among social workers. According to a social worker from the Peace Mission interviewed in 2017, some refugees and asylum seekers may not be aware of their own rights. In some cases, they do not know that they have the right to register with the CADÚnico to access social programs, or even that it exists. The minimum time during which a refugee can have access to the social programs provided by the CADÚnico is three months from the time they arrive in Brazil. However, this usually takes longer because the regulation process can be very slow, they do not have the information about their rights and sometimes, when they do, they still do not have the required documents to register for the program.

In addition, the registration of any immigrant with the CADÚnico can be done through the Reference Center for Social Assistance (CRAS). In theory, immigrants should be referred to CRAS when they are in the process of acquiring their documents from the Federal Police, and through civil society organizations that provide assistance to them. According to the social worker interviewed, CRAS has one central office and several local offices throughout the city of Sao Paulo. Some of these local offices do not provide support for refugees because they assume refugees need to go to the central office for assistance, when this is not the case.

Another problem related to the Bolsa Familia for refugees is related to the amount of money provided through the program, which is too little to fully respond to their specific needs. This amount is very little, especially for recipients who live in large urban areas, like São Paulo and Rio de Janeiro, where the costs of living are very high. In addition, some refugees have to send remittances to their families who live in another country. According to the social worker from Peace Mission, there are refugees and immigrants who, when they know the amount of money that the BFP offers, choose to not even register for the Bolsa Familia program. However, the social worker explained that, even though it is a small amount of money, the Bolsa Familia can be important to people in extreme poverty. Refugees usually receive donation from churches, mosques, NGOs and communities spread throughout the city. As refugees end up having to live on the outskirts of the city because of the high rent in central areas, the social assistance worker explained that they use the cash they earn from the program to pay for their commute to their informal work and to receive donations.

To compensate for a lack of assistance from the government, and, even more broadly, to overcome the general difficulties they face in the process of economic and social integration, mainly because of language barriers, immigrants and refugees end up relying on the social services provided by civil society organizations, especially NGOs and religious organizations. Even more importantly, they also rely on safety nets within communities with individuals from the same ethnic group or nationality or with other groups with whom they share some cultural and linguistic similarities. These safety nets, in some cases, start even before immigrants arrive in Brazil, and these connections may be one of the reasons why they choose to come to the country.

In relation to the Syrian refugees, there is a well-established Arab community in São Paulo that provides some assistance for them. Most of this assistance is organized and mediated by the mosques in São Paulo, and, as stated by a member of Brazil Mosque who was interviewed in 2019, generally their assistance is given to the entire needy population, including immigrants regardless of their origin. Brazil Mosque, the oldest and one of the largest mosques in Latin America, works in support of the low-income population through the donation of staple foods, cleaning supplies, mattresses, blankets, clothes, and also cash. According to this member of the mosque, these donations take place in the mosque and they also deliver assistance to the slums and poor communities.

For Syrians, in particular, the president of the mosque rented 40 furnished apartments between 2014 and 2018 to Syrian families with one-year contracts. The mosque was in charge of registering the families and they were selected to be in the apartments depending on their level of vulnerability, for example, depending on the family members' health conditions. In relation to work, the mosque received the refugees' curricula to send to companies that were registered in the mosque as well as people who were interested in hiring refugees to do housework, such as day care (MOTA, 2016). In addition, also according to this member from the mosque, there is a strong connection with the Arab community through social media, such as Facebook and Whatsapp groups, which provide assistance to the newcomers. One of the most common forms of support is related to the documentation process. Finally, the fact that refugees tend to live in clusters means they end up informing 
each other about social programs they are eligible to receive. For instance, one article from the BBC News reported that a Syrian refugee was not aware of the BFP until his neighbor, another Syrian refugee who had already been in Brazil for some time, told him about it (Bandeira, 2015).

In the absence of a coordinated structure to support refugees and while they have not been integrated into the formal job market, refugees have to rely on a rather complex, yet usually insecure and precarious structure built upon the intersection of social assistance, informal work, and support from civil society organizations and their communities. The charity support refugees receive from their communities is very important to the integration process, especially in an emergency context, but they are not able to resolve the economic vulnerabilities they face as formal social protection would. In addition, the need to find means within their ethnic niches can lead to a clustering of immigrants which may hinder the full process of social integration within society.

\section{CONCLUSION}

The central argument of this paper is that social protection structures play a very important role in the economic integration of refugees because they can guarantee a basic means for them and their families to survive while they have still not been integrated into the formal market. This can also help them become less vulnerable to forced labor and to being victims of discrimination and exploitation (UNHCR, 2019). In Brazil, the inclusion of refugees in the Bolsa Familia program represents an important contribution for the integration of refugees in terms of advancing their rights to access national public policies. However, in practice, there are problems that hinder the potential of the program to effectively integrate refugees into the society. The main problems identified in this article are a lack of information about their rights to access it, and the fact that the amount of money provided by the program is very small in terms of guaranteeing their economic integration, given all the specific needs that this population has.

Analyzing the specific case of Syrian refugees in São Paulo, this paper shows that they also receive support from the Arab community in the city, and some of these refugees have benefitted from its donations and access to work, for example, in addition to the formal structures of social protection provided by various levels of government. In other words, they benefit from a safety net that combines formal structures of social protection with support based on interpersonal and community ties.

Looking beyond this study, it is possible to identify some areas for further research. The first would be to conduct case studies about other communities based on nationalities or ethnic ties in São Paulo to understand the particular characteristics of their informal social protection structures. A comparative study among these groups would also help identify the main difficulties that each community faces in particular, and the main common problems among all the various immigrant communities. The second would be to analyze the abuses that exist within the informal networks that serve refugees in the absence of formal work. While this study has not shed light on the negative consequences of informality, it recognizes the importance to investigate these abuses within immigrant communities and among native citizens and immigrants. In addition, by addressing economic integration through the structures of social protection, the main policy recommendation is to advance the promotion of better coordination among the various actors in the public sector and civil society to guarantee a more solid structure to support refugees while they are not integrated into the country's formal economy.

Finally, since 2015 the political and economic turmoil in Venezuela has led to a refugee crisis in South America with exorbitant dimensions. By the end of 2019, according to the UNHCR website (UNHCR Emergencies, webpage), 4.5 million Venezuelan refugees were living in other South American countries and the number of Venezuelans seeking refuge in the region increased five times from 2017 to 2018. As mentioned before, CONARE had 61,681 Venezuelans registered as asylum seekers in 2018 (CONARE, 2019). This new chapter of the refugee crisis in the region requires greater effort from the Brazilian government, not only to provide them with asylum and to guarantee their refugee status, but also to rethink and redesign the social protection structures that are central to the economic integration of refugees. 


\section{REFERENCES}

Ager, A., \& Strang, A. (2008). Understanding Integration: a conceptual framework. Journal of Refugee Studies, 21(2), 166-191.

Ager, A., \& Strang, A. (2010). Refugee Integration: emerging trends and remaining agendas. Journal of Refugee Studies, 4(23), 509-606.

Bahar, D., Dooely, M., \& Huang, C. (2018). Integrating Venezuelans into the Colombian labor market. Washington, DC: Brookings Institute.

Bandeira, L. (2015, outubro 14). Sem programa específico para refugiados, Brasil põe centenas de sírios no Bolsa família. $B B C$ News Brasil. Retrieved from https://www.bbc.com/portuguese/ noticias/2015/10/151013_bolsa_familia_sirios_lab

Barban, F., Ilcan, S., \& Rygiel, K. (2017). Syrian Refugees in Turkey: pathways to precarity, differential inclusion and negotiated citizenship rights. Journal of Ethnic and Migration Studies, 43(1), 41-57.

Barrientos, A., \& Hulme, D. (2008). Social Protection for the Poor and Poorest: Concepts, Policies, and Politics. London, UK: Palgrave Macmillan.

Caixa Econômica Federal. (2017). Bolsa Família. Retrieved from http://www.caixa.gov.br/programas-sociais/bolsa-Família/Paginas/ default.aspx

Castles, S., Korac, M., Vasta, E., \& Vertovec, S. (2002). Integration: Mapping the Field (Report for the Home Office Immigration Research and Statistics Service). Oxford, UK: University of Oxford.

Comitê Nacional de Refugiados. (2013). Resolução Normativa CONARE № 17. Retrieved from https://www.conjur.com.br/dl/resolucaosiria-refugiados.pdf

Comitê Nacional de Refugiados. (2019). Refúgio em números (4a ed.). Retrieved from https://www.justica.gov.br/seus-direitos/refugio/ refugio-em-numeros

Fagundez, I. (2015, setembro 29). Em SP desde o século 19, comunidade síria se reúne para ajudar refugiados. Folha de S. Paulo. Retrieved from https://www1.folha.uol.com.br/saopaulo/2015/09/1683679em-sp-desde-o-seculo-19-comunidade-siria-se-reune-para-ajudarrefugiados.shtml

Godoy, G. (2011). O caso dos haitianos no Brasil e a via da proteção humanitária complementar. In G. Rodrigues, G. Almeida, \& A. Ramos (Orgs.), 60 anos de ACNUR: perspectivas de futuro. São Paulo, SP: Editora CL-A Cultural.

Grace, B., Nawyn, S., \& Okwako, B. (2017). The right to belong (if you can afford it): market-based restrictions on social citizenship in refugee resettlement. Journal of Refugee Studies, 31(1), 42-62.

Hainmueller, J., Hangartner, D., \& Lawrence, D. (2016). When lives are put on hold: Lengthy asylum processes decrease employment among refugees. Science Advances, 2(8), e1600432.

Haydu, M. (2011). A integração dos refugiados no Brasil. In G. Rodrigues, G. Almeida, \& A. Ramos (Orgs.), 60 anos de ACNUR: perspectivas de futuro. São Paulo, SP: Editora CL-A Cultural.

Hynie, M. (2018). Introduction to the Special Issue: Refugee Integration: Research and Policy. Peace and Conflict: Journal of Peace Psychology, 24(3), 265-276.
International Labour Organization. (2018). Inserção Laboral de Migrantes Internacionais: transitando entre a economia formal e informal no município de São Paulo. Retrieved from http://www.ilo. org/brasilia/publicacoes/WCMS_615540/lang--pt/index.htm

Jubilut, L. (2015). Migrantes, apátridas e refugiados: subsídios para o aperfeiçoamento de acesso a serviços, direitos e políticas públicas no Brasil. Brasília, DF: Ministério da Justiça, Secretaria de Assuntos Legislativos.

Kuhlman, T. (1991). The economic integration of refugees in developing countries: a research model. Journal of Refugee Studies, 4(1), 1-20.

Lein. 16,478, de 08 de julho de 2016. (2016). Institui a Política Municipal para a População Imigrante, dispõe sobre seus objetivos, princípios, diretrizes e ações prioritárias, bem como sobre o Conselho Municipal de Imigrantes. São Paulo, SP. Retrieved from https://www.legisweb. com.br/legislacao/?id=325960

Mantovani, F. (2019, outubro 23). Mapa mostra onde vivem refugiados em São Paulo. Folha de S. Paulo. Retrieved from https://www1.folha. uol.com.br/mundo/2019/10/mapa-mostra-onde-vivem-refugiadosem-sao-paulo.shtml

Martinez, M. (2015, September 10). Syrian Refugees: which countries welcome them, which ones don't. CNN. Retrieved from https:// edition.cnn.com/2015/09/09/world/welcome-syrian-refugeescountries/index.html

Mayadas, N., \& Elliott, D. (1992). Integration and Xenophobia: An Inherent Conflict in International Migration. Journal of Multicultural Social Work, 2(1), 47-62.

Ministerio da Cidadania. (2019). Bolsa Família atende mais de 13,5 milhões de beneficiários em setembro. Retrieved from http://mds. gov.br/area-de-imprensa/noticias/2019/setembro/bolsa-familiaatende-mais-de-13-5-milhoes-de-beneficiarios-em-setembro

Moreira, J. (2010). Redemocratização e direitos humanos: a política para refugiados no Brasil. Revista Brasileira de Política Internacional, 53(1), 111-129.

Moreira, J., \& Borba, J. (2017). Syrian Refugees in Sao Bernardo do Campo: interaction between a religious institution and the municipal government within the local integration process. Revista de Estudos Internacionais, 8(3), 105-117.

Mota, C. V. (2016, janeiro 21). Mesquita em São Paulo guarda 2000 currículos. Valor Econômico. Retrieved from https://valor.globo. com/brasil/noticia/2016/01/21/mesquita-em-sao-paulo-guarda-2mil-curriculos-1.ghtml

Nawyn, S. (2011). "I Have so Many Successful Stories": Framing Social Citizenship for Refugees. Citizenship Studies, 15(6-7), 679-693.

Netto, G. (2011). Strangers in the City: addressing challenges to the protection, housing and settlement of refugees. Journal of Housing Policy, 11(3), 285-303.

Observatorio das Migrações em São Paulo. (2017). Banco Interativo Observatório das Migrações em São Paulo-Imigrantes internacionais com a condição de refúgio registrados no Sistema Nacional de Cadastros e Registros de Estrangeiros (SINCRE), entre 2000-2016, nascidos na Síria e residentes no Estado de São Paulo. Retrieved from 
https://unicamp-arcgis.maps.arcgis.com/apps/opsdashboard/index. html\#/9d66a6e333be4f4aa09028daf619968e

Organização Internacional para as Migrações, \& Secretaria Municipal de Direitos Humanos e Cidadania. (2019). Indicadores da Governança Migratória Local. A Cidade de São Paulo. São Paulo, SP: Author. Retrieved from https://brazil.iom.int/sites/default/files/Publications/ mgi-layout-sao\%20paulo\%20copy_PT_for \%20printupdated.pdf

Portal Brasil. (2016, setembro 14). Governo prorroga visto humanitário para haitianos. Retrieved from http://www.brasil.gov.br/cidadania-ejustica/2016/09/governo-prorroga-visto-humanitario-para-haitianos

Rego, W. L., \& Pinzani, A. (2013). Vozes do Bolsa Família: autonomia, dinheiro e cidadania. São Paulo, SP: UNESP.

Rodrigues, A. (2019, dezembro 06). Conare reconhece condição de refugiados de mais de 21 mil venezuelanos. Agência Brasil. Retrieved from https://agenciabrasil.ebc.com.br/direitos-humanos/ noticia/2019-12/conare-reconhece-condicao-de-refugiados-mais-de21-mil-venezuelanos

Şimşek, D. (2018). Integration Processes of Syrian Refugees in Turkey: 'Class-based Integration'. Journal of Refugee Studies, 33(3), 537-554. Retrieved from https://doi.org/10.1093/jrs/fey057
UN General Assembly. (1951). Convention Relating to the Status of Refugees. New York, NY: Author.

United Nations High Commissioner for Refugees. (2013). A New Beginning: Refugees Integration in Europe. Outcome of an EU funded project on Refugee Integration Capacity and Evaluation (RICE). Retrieved from http://www.refworld.org/pdfid/522980604.pdf

United Nations High Commissioner for Refugees. (2019). Global Appeal UNHCR 2019 Update. Retrieved from http://reporting.unhcr. org/sites/default/files/ga2019/pdf/Chapter_PoC.pdf

United Nations High Commissioner for Refugees. (2019). Refugee livelihoods and economic inclusion: 2019-2023 Global Strategic Concept Work. Retrieved from https://www.unhcr.org/publications/ operations/5bc07ca94/refugee-livelihoods-economic-inclusion-20192023-global-strategy-concept.html

United Nations High Commissioner for Refugees. (2020). Emergencies. Venezuela Situation. Retrieved from https://www.unhcr.org/venezuelaemergency.html

United Nations High Commissioner for Refugees. (2020). Help Brazil. Asylum claim, Residence and Naturalization. Retrieved from https:// help.unhcr.org/brazil/en/asylum-claim

André Cavaller Guzzi

ORCID: https://orcid.org/0000-0002-6749-299X

Ph.D. in Political Science from the City University of New York (CUNY); Hourly professor at the Getulio Vargas Foundation (FGV EAESP), São Paulo SP, Brazil. E-mail: andre.guzzi@fgv.br 